\title{
Teaching NeuroImages: Not a typical spinal mass
}

Tarun D. Singh, MBBS, Amy Swanson, MD, Anthony M. Burrows, MD, Michelle Clarke, MD, Sejal Shah, MD, Farwa Ali, MBBS, and Elizabeth A. Coon, MD

Neurology ${ }^{\circledR}$ 2018;91:e790-e791. doi:10.1212/WNL.0000000000006031

\section{Correspondence}

Dr. Coon

coon.elizabeth@mayo.edu

Figure $1 \mathrm{MRI}$ of the spine

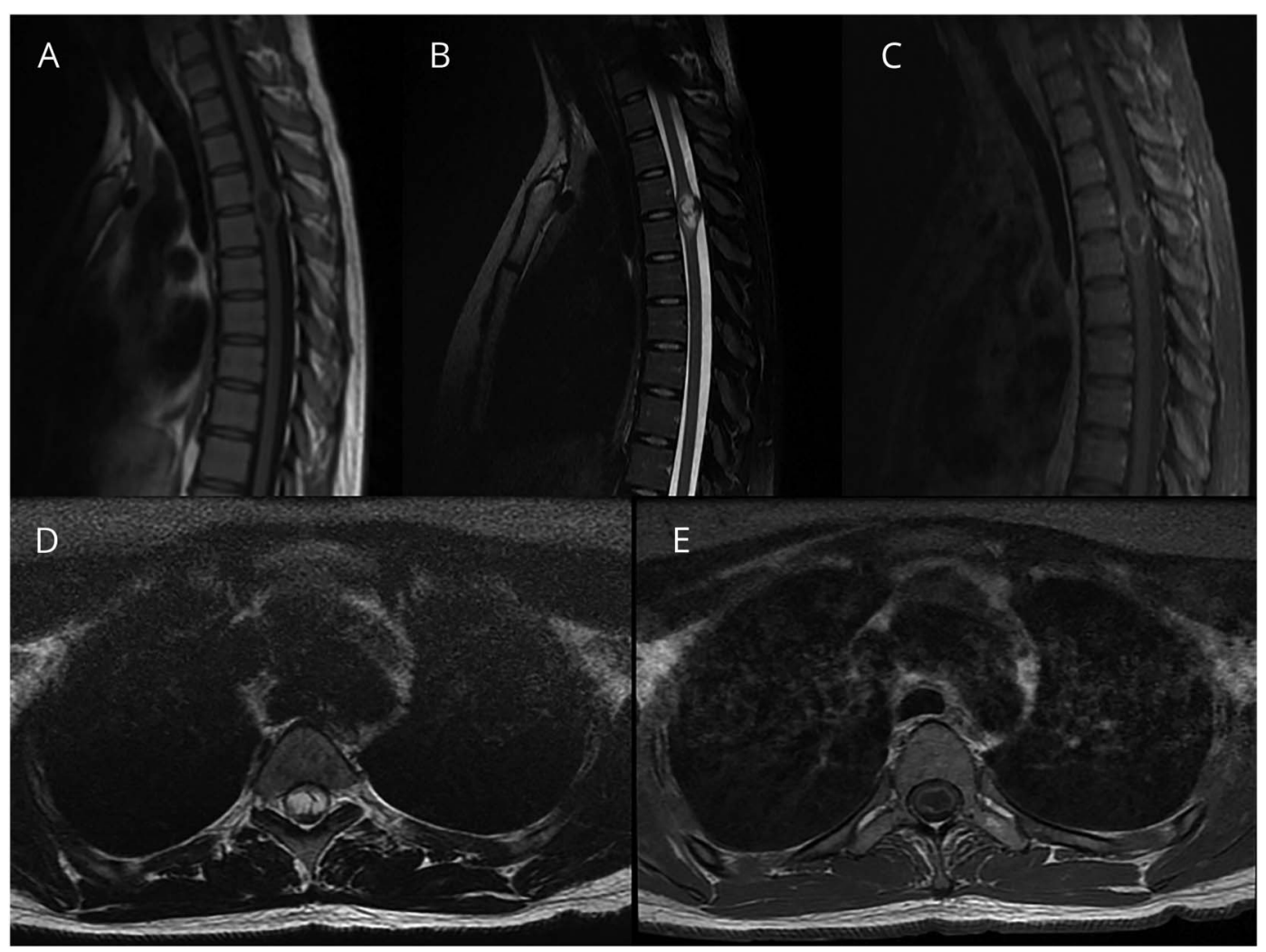

(A) Sagittal T1-weighted, (B) sagittal T2-weighted, (C) sagittal T1 with contrast, (D) axial T1-weighted, and (E) axial T1-weighted with contrast show the presence of an expansile, peripherally enhancing lesion at the level of T4-T5 with curvilinear areas of T2 hypointensity within the lesion and minimal surrounding edema, with no evidence of spinal malformations.

A 20-year-old woman presented with subacute progressive lower extremity weakness and spasticity. Examination findings were consistent with Brown-Sequard syndrome. Thoracic spine MRI/magnetic resonance angiography showed an intramedullary mass (figure 1). During gross total resection, the mass had a pearlescent appearance, while histopathologic examination was consistent with epidermoid cyst (figure 2).

Spinal epidermoid cysts comprise $0.5 \%-1 \%$ of all spinal tumors, with congenital epidermoid tumors manifesting between the second and fourth decades, rarely intramedullary. ${ }^{1}$ Because of the signal intensity similar to that of CSF, they are often misdiagnosed as other cystic
MORE ONLINE

\section{$\rightarrow$ Teaching slides}

links.lww.com/WNL/

A639 


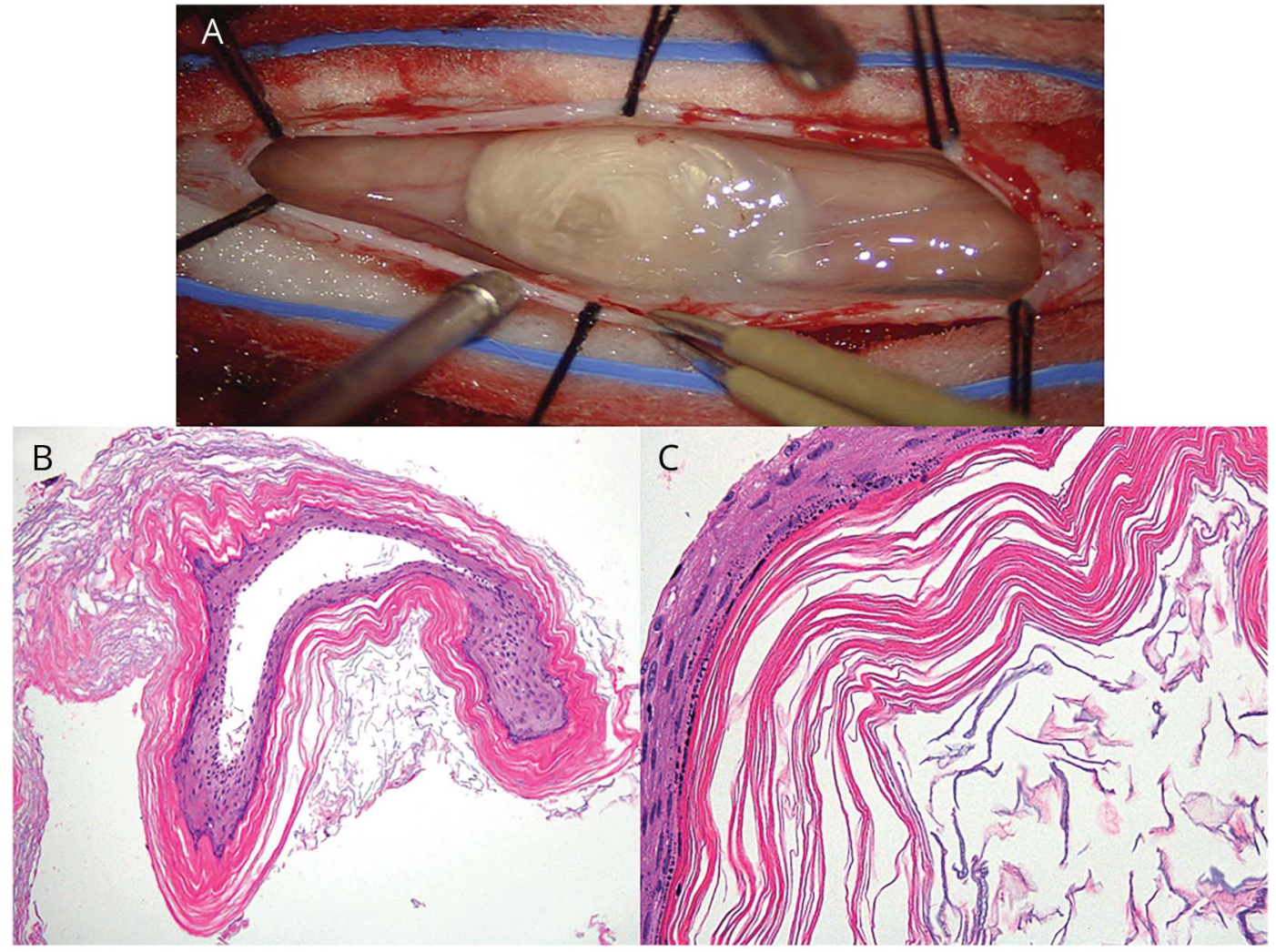

(A) Intraoperative image of the cyst. Hematoxylin \& eosin staining under (B) low power (100x) and (C) high power (400x) demonstrates a cystic structure lined by stratified squamous epithelium with a visible granular layer and prominent laminated keratin.

tumors. Treatment is surgical excision with recurrence rate inversely proportional to resection magnitude. ${ }^{2}$

\section{Author contributions}

Study concept and design: Dr. Coon, T.D. Singh. Acquisition, analysis, or interpretation of images: T.D. Singh, Dr. Swanson, Dr. Burrows, Dr. Clarke, Dr. Shah, F. Ali, and Dr. Coon. Drafting of the manuscript: T.D. Singh, Dr. Coon. Study supervision: Dr. Coon. Critical revision of the manuscript: T.D. Singh, Dr. Swanson, Dr. Burrows, Dr. Clarke, Dr. Shah, F. Ali, Dr. Coon.

\section{Study funding}

No targeted funding reported.

\section{Disclosure}

The authors report no disclosures relevant to the manuscript. Go to Neurology.org/N for full disclosures.

\section{References}

1. Ziv ET, McComb J, Krieger MD, et al. Iatrogenic intraspinal epidermoid tumor: two cases and a review of the literature. Spine 2004;29:E15-E18.

2. Gonzalvo A, Hall N, McMahon JH, et al. Intramedullary spinal epidermoid cyst of the upper thoracic region. J Clin Neurosci 2009;16:142-144. 


\title{
Neurology
}

\author{
Teaching NeuroImages: Not a typical spinal mass \\ Tarun D. Singh, Amy Swanson, Anthony M. Burrows, et al. \\ Neurology 2018;91;e790-e791 \\ DOI 10.1212/WNL.0000000000006031
}

This information is current as of August 20, 2018

\section{Updated Information \& Services}

\section{References}

Subspecialty Collections

Permissions \& Licensing

Reprints including high resolution figures, can be found at: http://n.neurology.org/content/91/8/e790.full

This article cites 2 articles, 0 of which you can access for free at: http://n.neurology.org/content/91/8/e790.full\#ref-list-1

This article, along with others on similar topics, appears in the following collection(s):

\section{All Neuromuscular Disease}

http://n.neurology.org/cgi/collection/all_neuromuscular_disease All Spinal Cord

http://n.neurology.org/cgi/collection/all_spinal_cord

MRI

http://n.neurology.org/cgi/collection/mri

Peripheral neuropathy

http://n.neurology.org/cgi/collection/peripheral_neuropathy

Information about reproducing this article in parts (figures,tables) or in its entirety can be found online at:

http://www.neurology.org/about/about_the_journal\#permissions

Information about ordering reprints can be found online:

http://n.neurology.org/subscribers/advertise

Neurology ${ }^{\circledR}$ is the official journal of the American Academy of Neurology. Published continuously since 1951, it is now a weekly with 48 issues per year. Copyright @ 2018 American Academy of Neurology. All rights reserved. Print ISSN: 0028-3878. Online ISSN: 1526-632X.

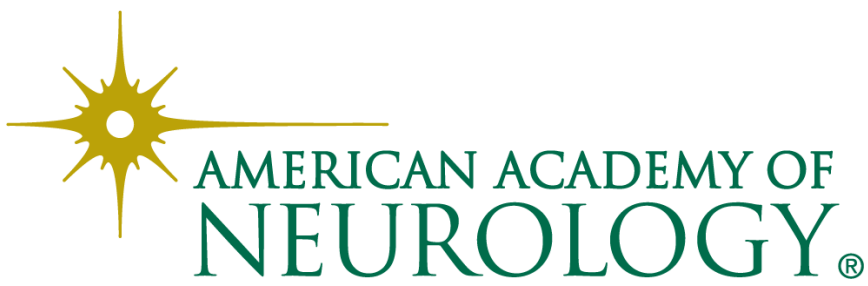

